\title{
the vanuatu cultural centre's juvenile justice project
}

\author{
Joemela Simeon \\ Project Manager \\ Juvenile Justice Project, Vanuatu Cultural Centre
}

IF SOMEONE had asked me to define restorative justice, back in April this year before I began work on the Juvenile Justice Project, I would honestly have said that I did not have a single clue about its meaning. However, I agree entirely with the Honourable Sela Molisa (who spoke at the opening of the conference) and a number of other contributors to this volume, in acknowledging that, although the term 'restorative justice' may be foreign, it nonetheless refers to a practice that has been used in most, if not all, of our Melanesian societies prior to our colonisation.

\section{Rationale of the Juvenile Justice Project}

This project will address the needs and rights of juvenile offenders who, in Vanuatu, are defined as those under eighteen years of age. The Vanuatu Constitution explicitly states that 'customary law shall continue to have effect as part of the law of the Republic of Vanuatu' (Section 95 (1)). Currently a system of kastom law operates in Vanuatu at village level through the chiefs and through a system of area and island courts. While the effectiveness of this system varies greatly from island to island, it is nonetheless a system which is functioning and which meets the needs of community members to facilitate the resolution of local problems. An example of this sort of dispute resolution forum is the Lakalakabulu Area Council of Chiefs of North Ambae (see 
Vuhu in this volume). This body has been effectively dealing with land and social problems since its establishment in 1996. It has dealt with problems of young people in both North Ambae and Port Vila. So too are other islands and island communities in Port Vila using traditional approaches to facilitate dispute resolution.

There is currently an ongoing national discourse about returning power to the chiefs, particularly in the area of dealing with young offenders in town. More recently the Ministry of Justice, Culture and Women's Affairs has talked of developing a system of traditional courts in Port Vila. Some communities such as Blacksands have already initiated it. However there is, on the basis of recent experiences in Blacksands, a considerable need to reconsider how the traditional system of law can be more effectively adapted for use in urban and peri-urban communities. The situation is decidedly more complex with the co-existence of many different island communities living within one area, each with different approaches to conflict resolution. In addition, in urban areas traditional compensation items such as pigs, mats and kava (fermented juice of a plant of the pepper family) are not readily available. Such matters need to be considered in any proposal for utilising kastom methodologies in urban areas. While this project is confined to assessing issues of juvenile justice, it will undoubtedly encounter more fundamental questions related to the contemporary relevance and applicability of kastom law. The project will seek to involve the broadest possible range of relevant parties, from the government and the judiciary to kastom leaders, women and youth representatives, churches and NGOs.

Currently the judiciary, under the Acting Chief Justice Mr Vincent Lunabek, is very receptive to addressing the problems of young offenders and avoiding their incarceration through the use of kastom approaches. There is also considerable interest in the Public Solicitor's Office in a more effective utilisation of traditional or kastom approaches in addressing problems associated with young offenders. The Juvenile Justice Project provides an unprecedented opportunity to work with the judiciary and court system in exploring these possibilities. 
The treatment of young offenders in Vanuatu is currently left to the discretion of Western courts. However, it is important that the specific needs and rights of young offenders are not only recognised formally within the legal system, but are addressed. For example, there is a provision in the Penal Code (Cap 135) that young people under 16 years of age should not serve sentences with older prisoners. There is, however, no separate detention area for young people and this can result in their incarceration in the main gaol. It can also lead the police to meting out 'informal justice' in anticipation of the likely release of the juvenile.

A number of important questions need to be addressed in the course of the project:

- $\quad$ is it possible to deal with juvenile offenders through the kastom system and thereby bypass the court system?

- how will cases defined as criminal or civil be negotiated?

- how will the key notion of responsibility at the individual, family and community levels be defined?

The Juvenile Justice Project has emerged from the findings of an ongoing research project with the Vanuatu Cultural Centre - the Vanuatu Young People's Project (VYPP) and in the course of discussions with young people. Many young people, particularly males who are more likely to be young offenders, stated that they preferred to have their disputes resolved and offences addressed through utilisation of existing customary approaches rather than through the Western legal system. Young offenders who were interviewed voiced concerns about the treatment they had received from police. They expressed unfavourable views about the punitive consequences associated with the Western court system and pointed to their preference for customary reconciliation. A more general problem that young people identified in their dealings with the law, was a lack of understanding of the Western legal system and their rights under this system. Of particular interest to the Centre was the finding that it is in the area of juvenile justice that kastom was seen as most relevant to young people. 


\section{The project's objectives}

To date the project has five objectives:

1 to develop a plan of action to effectively address the needs and rights of young offenders;

2 to undertake research on customary (kastom) approaches to the issue of young offenders and justice and the conceptions, principles and practices involved therein;

3 to initiate a broad-based and participatory process of discussion around issues of juvenile justice, culminating in a national summit meeting;

4 to identify the strategy and mechanisms needed to develop and provide an alternative system which effectively negotiates and incorporates customary and Western legal conceptions of justice to respond in a positive way to the situation of young offenders in Vanuatu;

5 to provide expertise and training on issues of juvenile justice and alternative dispute resolution to staff of the Young People's Project at the Vanuatu Cultural Centre. A number of project activities will be undertaken.

\section{Research and consultation process}

A plan of research and consultation will be developed in order to ensure that the key questions and issues are addressed. Consultation will be with the widest and most representative range of people and parties possible. It is envisaged that locations where customary law initiatives already exist on the islands of Malekula, Tanna, Santo, Ambrym, Pentecost and Ambae will be covered in the research and consultation process. In addition, the settlements of Blacksands, Ohlen, Wallis, Malapoa, Freswota and Seaside Paama, Tongoa and Futuna in Port Vila will be covered, as well as the settlements of Palm station, Sarakata, Side River, Banban and Manoo in Luganville. Of central importance to this process will be close collaboration and intensive consultation with kastom leaders and representatives of the existing Western legal system, particularly from the courts at village, island and national levels, the Police Department, the Public Prosecutor's Office and the State Law Office. 


\section{Training and orientation of project staff in the field of juvenile justice}

The expertise afforded by the Advisory Committee, the Law School of the University of the South Pacific, and other international advisers, will be utilised to guide the research process and the development of the research methodology and plan of action. Advisers with experience in existing programs of alternative dispute settlement and restorative justice will provide additional training in the theory and practice of restorative justice to project staff and staff of the Young People's Project.

\section{Organisation of national summit meeting}

Key individuals and organisations including chiefs, community leaders, young people, court representatives and police will be brought together for discussion and the development of recommendations, which will become part of the plan of action. The Vanuatu Cultural Centre will record this meeting on videotape for documentation and archival purposes.

\section{Drafting of a plan of action}

The draft plan of action will emerge from the research and consultation process and will be discussed at the national summit meeting at which time recommendations from the meeting will be included in the final draft.

The Juvenile Justice Project is currently in its final preparations for the first round of research. The research component of the project will begin in July 2000.

The duration of the project is fifty-seven weeks. At the end of this period, it is intended that the project will have achieved the following outcomes:

- a plan of action for addressing the needs of young offenders;

- a report of the research process and findings and a summary report of the national summit meeting;

- video coverage of the summit meeting for archival purposes; 
- $\quad$ the development of awareness of rights and needs among communities and the development of skills and knowledge in addressing these complex issues;

- $\quad$ the development of a more comprehensive understanding of customary justice principles.

\section{The benefits of the project in summary:}

1 The development of a comprehensive plan of action for addressing the needs of young offenders in Vanuatu based on extensive research and consultation with all stakeholders;

2 The development of a more comprehensive understanding of customary law principles, which may then be applicable in the broader context of national law reform;

3 The discharging of a significant step towards fulfilling Vanuatu's obligation to implement the United Nations' Convention on the Rights of the Child (particularly Article 40);

4 Increased awareness among young people and communities of their rights and the development of skills and knowledge for addressing issues affecting those rights. 